Role of agricultural engineering in environmental and sustainable development for the valley and delta areas: 1572 - 1587

\title{
PERFORMANCE OF RICE STRAW CHOPPER AND ENVIRONMENT PRESERVATION
}

\section{Hamada El-Khateeb Mohamed Khodeir Abdel-Gawad A. Soliman}

\section{ABSTRACT}

Crop residues are one of the most critical problems which face the Egyptian farmer specially after harvesting crops such as rice cotton and other different farm crops.

Field experiments were conducted at Rice Mechanization center, Meet El - Deeba, Kafr El - Sheikh Governorate during summer season of 2009/2010. The present study was carried out by using a straw chopper to show the effect of straw moisture content (40.0, 25.0, and $15.0 \%$ ), machine forward speed $(2.0,3.1$, and $4.5 \mathrm{~km} / \mathrm{h})$ and different cutter head knives speed $(23.0,26.5,29.5$, and $33.0 \mathrm{~m} / \mathrm{s})$ on chopping length, machine capacity, chopping efficiency, degree of destruction, energy requirements and unit cost. The results indicated that increase the forward speed from $(2.0$ to $4.5 \mathrm{~km} / \mathrm{h})$ tends to increase the chopping length from (14.0 to $17.0 \mathrm{~mm})$, machine capacity $(1.50$ to $1.70 \mathrm{Mg} / \mathrm{h})$, energy required $(3.198$ to $3.717 \mathrm{~kW} . \mathrm{h} / \mathrm{Mg})$ and unit cost from $(5.50$ to $7.90 \mathrm{LE} / \mathrm{Mg}$ ), respectively. Whilst, the increase of cutter head knives speed from (23.0 to $33.0 \mathrm{~m} / \mathrm{s})$ tends to decrease the chopping length from (14.0 to $10.5 \mathrm{~mm})$ and increase energy required $(2.593$ to 3.198 $\mathrm{kW} . \mathrm{h} / \mathrm{Mg})$, chopping efficiency $(79.0$ to $88.0 \%)$ and degree of destruction (52.0 to $62.0 \%$ ), respectively. Also, straw moisture content of $40.0 \%$ gave the highest values of machine capacity, chopping length, chopping efficiency and degree of destruction as follows $(1.70 \mathrm{Mg} / \mathrm{h}$, $10.5 \mathrm{~mm}, 91.0 \%$ and $65.0 \%$, respectively ).

\section{INTRODUCTION}

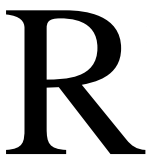
ice straw are currently used by farmers as fuel. Roof-tap storage of rice straw bundles presents a serious fire hazard, besides it summer season, most of the Egyptian farmers feed their livestock on very poor quality roughage such as rice and wheat straw.

Agric. Eng. Res. Inst. (AEnRI) - Dokki - Giza - Egypt.

The $17^{\text {th }}$. Annual Conference of the Misr Society of Ag. Eng., 28 October, $2010 \quad-1572-$ 
The decrease of forage crops during this period seems to be a serious problem in the nutritional requirements of animal. Crop residues are one of the most critical problems which face the Egyptian farmer specially after harvesting crops such as rice cotton and other different farm crops. Therefore the Egyptian farmers burn yearly about 3.9 million tons of cotton stalks and rice straw for disposing it and to save time to prepare the land for next crops. On the other side the quantity of crop residues in Egypt reached about 18.7-25.0 million tons on per year and the national income might be increased with 1.6 billion LE/year if we try to recycle it. Forage chopper is considered to be an applying solution for labour shortage and its usually one part of a system that permits complete mechanization of chopper straw and feeding. Tractor mounted type chopper is most popular type in Egypt, because it suitable for small farms, and it have high productivity with smaller horsepower tractors. The effect between different speeds of cutter head and number of knives for cutting some field crop residues such as cotton stalks, maize stalks, bean stalk and rice straw and its effect on the power requirement and cutting length. It was found that the cutting length decreased by increasing knives number and cutter head drum speed (Khadder, 1997). $\mathrm{He}$ also added that increasing cutter head knives from 2 to 4 knives decreased the horsepower consumed; meanwhile, increasing cutter head drum speed cause an increase in the horsepower consumed. The cutting corn stalks at moisture content of $40.22 \%$, cutter head speed of $27.65 \mathrm{~m} / \mathrm{s}$ and feeding mechanism speed of $0.41 \mathrm{~m} / \mathrm{min}$ produced the maxmum value of unit energy $(2.08 \mathrm{~kW} . \mathrm{h} / \mathrm{ton})$. Meanwhile, the minimum value of cutting length $(12.24 \mathrm{~mm})$ was obtained with same treatments at corn moisture content of $(62.82 \%)$, (Imara, et al. 1998) evaluated some operating parameters for forage harvester, thy mentioned that the affecting on power and energy requirements. (Mohamed, et al. 1999 ) mentioned that the highest value of the energy consumption were (4.11 $\mathrm{kW} . \mathrm{h} / \mathrm{ton}$ ) was occurred by using $12 \mathrm{knives}$ at speed of $6.4 \mathrm{~km} / \mathrm{h}$ and $35.4 \%$ moisture content. While the lowest energy consumption were ( 1.8 $\mathrm{kW} . \mathrm{h} / \mathrm{ton}$ ) was obtained by using 4 knives at speed of $2.5 \mathrm{~km} / \mathrm{h}$ and 76.5\% moisture content. ( Tarek et al. 2001 ) developed a rice straw chopper. Their results showed that the productivity of the developed machine was $0.95 \mathrm{ton} / \mathrm{h}$ at $2000 \mathrm{rpm}$ rotor speed and cut length of ( 1 - 9 $\mathrm{cm}$ ) reached 95.235 from the total amount of cut residue. ( Kamel et al. 
2003 ) utilized of forage chopper for chopping rice straw. They found that the maximum distribution percentage of short pieces ( $56.53 \%)$ was obtained when using 12 - knives at $1.22 \mathrm{~m} / \mathrm{s}$ forward speed and $39.69 \%$ straw moisture content. Also, the maximum energy requirement ( 27.4 $\mathrm{kW} . \mathrm{h} / \mathrm{fed}$ ) was obtained for chopping rice straw under forward speed of $0.53 \mathrm{~m} / \mathrm{s}$ and moisture content of $13.49 \%$ with 12 cutter head knives. ( Ebaid, 2006 ) used corn Sheller for chopping cotton and corn stalks. He mentioned that the cutting length category percentage at these condition was 63 and $45.4 \%$ in cut length of less than $3.35 \mathrm{~cm}$ for corn and cotton stalk residues, respectively. It was found that the chop operation cost was estimated at 13.33 LE/ton and $20 \mathrm{LE} /$ ton for cutting corn and cotton stalk residues, respectively. (Metwally et al. 2006 ) developed and evaluate technically and economically the feeding and cutting mechanisms of chopping machine to be used for cutting the different crop residuals and pruning the fruit tree branches. They mentioned that increasing both feeding and cutting speeds tended to increase the actual capacities of chopping machine. The actual capacity of developed chopping machine increased by $28.6 \%$ when the cutting speed increased from 0.75 to $1.88 \mathrm{~m} / \mathrm{s}$, while it decreased by $52.05 \%$ as a result to decrease the cutting speed from 1.22 to $0.28 \mathrm{~m} / \mathrm{s}$ with the cutting knife of serrated edge shape. ( Arfa, 2007 ) modified the stationary thresher machine to become suitable for chopping and cut farm crop residues. of $1.5 \mathrm{ton} / \mathrm{h}$, moisture content of $14.3 \%$ and concave clearance Oval the slops area of $4 \mathrm{~cm}^{2}$ drum speeds of $18.33 \mathrm{~m} / \mathrm{s}$, feeding rates of $3 \mathrm{~cm}$, resulting in cutting length percentage of $82.1,85.6$ and $80.1 \%$ less than $3.5 \mathrm{~cm}$ for rice straw, corn stalks and cotton stalks, respectively. Energy requirement were found to be 29.9, 27.3 and $25.8 \mathrm{~kW} . \mathrm{h} /$ ton for rice straw, corn stalks and cotton stalks. The maximum operation cost was $25.0 \mathrm{LE} / \mathrm{h}$ and 17.0LE/ton for rice straw.( El-Khteeb, 2007 ) mentioned that increasing the cutter head speed from ( 22.1 to $35.3 \mathrm{~m} / \mathrm{s}$ ) tend to increase percentage of chopping length 0.5 to $2.0 \mathrm{~cm}$ from ( 50 to $60 \%$ ), degree of destruction from ( 28.7 to $38.2 \%$ ), machine productivity from ( 1.32 to $2.81 \mathrm{Mg} / \mathrm{h}$ ), useful power from ( 2.19 to $3.86 \mathrm{~kW}$ ), and with decreasing the unit energy required from ( 1.87 to $1.37 \mathrm{~kW} . \mathrm{h} / \mathrm{Mg}$ ) and chopping machine cost from ( 16.33 to $7.22 \mathrm{~L} . \mathrm{E} / \mathrm{Mg}$ ) at number of knives 2 and corn stalk moisture content of $65.0 \%$. 
The main objective of the this study is maximization of forage chopper and to reduce its hourly operating cost through studying the operating parameters affecting on the cutting length, power consumption and energy requirements for chopper rice straw residues using forage chopper.

\section{Materials and Methods}

Field experiments were conducted at Rice Mechanization Center, Meet El-Deeba, Kafr El-Sheikh Governorate during summer season of 2009/2010. The obtained windrows of rice straw was Giza-177 variety after harvesting rice by combine harvester were used for chopping using the forage chopper. The straw weight $\left(\mathrm{kg} / \mathrm{m}^{2}\right.$ or ton/fed) at given different straw moisture content. It was planted during the summer season of 2009/2010, to evaluate the effect of straw moisture content (40.0, 25.0, and 15.0\%), machine forward speed (2.0, 3.1, and $4.5 \mathrm{~km} / \mathrm{h}$ ) and different cutter head knives speed $(23.0,26.5,29.5$, and $33.0 \mathrm{~m} / \mathrm{s})$ on chopping length, machine capacity, chopping efficiency, degree of destruction, power consumption, energy requirements and unit cost

\section{Equipment}

The forage chopper was mounted on the $65 \mathrm{hp}$ NASR tractor ( $48.51 \mathrm{~kW}$ ) during chopping rice straw in the present study. The main components of this chopper are shown in Fig.1 and technical specifications of this chopper are summarized in Table1.

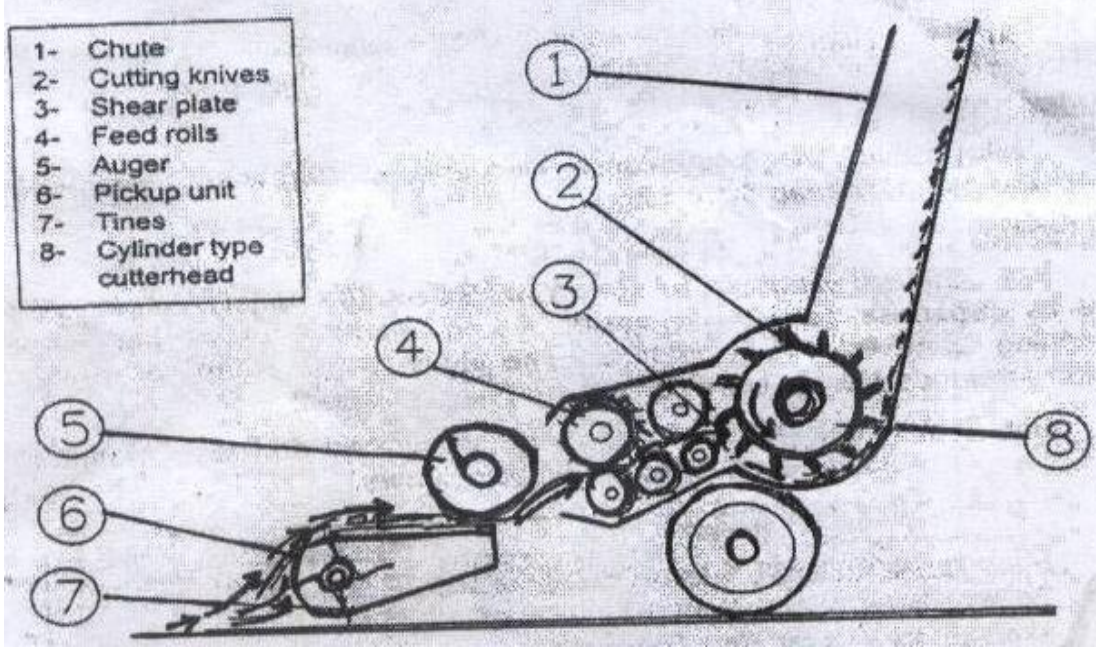

Fig.1: Schematic diagram shows the main components of the chopper and chopping material flow. 
Table 1: Technical specifications of the forage chopper.

\begin{tabular}{|l|c|}
\hline Item & Specification \\
\hline Source of manufacture & Italy \\
\hline Type & Mounted \\
\hline Gathering ( pickup ) with, $\mathrm{mm}$ & 1200 \\
\hline Chopping unit dimension, $\mathrm{mm}$ & $500 \times 1200$ \\
\hline Cutter head width, $\mathrm{mm}$ & 320 \\
\hline Cutter head diameter, $\mathrm{mm}$ & 500 \\
\hline No. of knives on cutter head & 12 or 6 or 3 \\
\hline Cutter head speed, $\mathrm{rpm}(\mathrm{m} / \mathrm{s})$ & $1250(28.8)$ \\
\hline Throat cross- sectional area, $\mathrm{mm}$ & $300.5 \times 130$ \\
\hline
\end{tabular}

The forage chopper include the following basic, functional components:

1- A gathering unit to pickup windrowed material.

2- A conveying and feed mechanism to compress and hold the material for chopping.

3- A cutter head or chopping unit to chop material for small lengths.

\section{Instruments:}

Digital vernier, weighing balance, electric oven, stop watch, wooden frame $1 \mathrm{~m}^{2}$ and measuring tap $50 \mathrm{~m}$ long.

\section{Measurements:}

The following items were measured during evaluating the forage chopper under the study parameters:-

\section{1- Theoretical and actual lengths of cut:}

The theoretical length of cut, $\mathrm{L}_{\text {th }}$ was calculated using the following equation according to Srivastava, et. al. 1995.

$L_{\text {th }}=60000 V_{\mathrm{f}} / \eta_{\mathrm{c}} \lambda_{\mathrm{k}}, \mathrm{mm}$

Where:

$\mathbf{V}_{\mathbf{f}}=$ Feed velocity, $\mathrm{m} / \mathrm{s}$ ( = peripheral speed of feeding rolls $)$.

$\boldsymbol{\eta}_{\mathbf{c}}=$ Cutter head rotational speed, $\mathrm{rpm}$.

$\lambda_{\mathbf{k}}=$ Number of knives on the cutter head.

After each chopping treatment, random samples ( $1 \mathrm{~kg}$ each ) were taken from chopped material the laboratory and separated to determine the actual mean of cutting length ( $\mathrm{Lac}$ ). Each cutting length in the sample 
was weighed and calculated as a percentage in proportional to the total weight of the sample.

\section{2- Machine productivity:-}

Was calculated by using the following formula (Mady, 1999);

$\mathbf{P}=\mathbf{W} \times \mathbf{3 6 0 0} / \mathbf{T}, \mathbf{M g} / \mathbf{h}, \ldots \ldots \ldots \ldots \ldots \ldots \ldots \ldots \ldots \ldots \ldots \ldots . \ldots \ldots$

Where:

$\mathbf{P}=$ Productivity in $\mathrm{Mg} / \mathrm{h}$;

$\mathbf{W}=$ mass of the sample in $\mathrm{Mg}$, and

$\mathbf{T}=$ time in sec.

\section{3- Degree of destruction of the rice stem borer :-}

The infection was counted before and immediately after chopping operation in area $\mathrm{m}^{2}$ and calculated by using the following formula Hanna et al. 1985

Degree of destruction, \% = F $-\mathrm{L} / \mathrm{F} \times 100$,

Where:

$\mathbf{F}=$ Number of infested rice stem borer before chopping, $\mathrm{m}^{2}$

$\mathbf{L}=$ Number of infested rice stem borer after chopping operation, $\mathrm{m}^{2}$

\section{4- Chopping efficiency:}

The chopping efficiency ( Ec) was calculated by using the following formula, Cravcenco, et. al. 1976.

$\mathbf{E c}=\mathbf{W b}-\mathrm{Wa} / \mathrm{Wb} \times 100, \%$ 4

Where:

$\mathbf{W b}=$ Weight of rice straw in area $\mathrm{m}^{2}$ before chopping operation, $\mathrm{kg}$.

$\mathbf{W b}=$ Weight of rice straw pieces which has length greater than $5 \mathrm{~cm}$ in area $\mathrm{m}^{2}$ after chopping operation, $\mathrm{kg}$.

\section{5- Required power:}

Chopping energy requirements were estimated by using the following formula, Embaby 1985.

$$
\left.\mathrm{kW} \frac{1}{1.36} \times \frac{1}{75}\right) \rho_{\mathrm{F}} \times \text { L.C.V. } \times 427 \times \eta_{\text {th }} \times \eta_{\mathrm{m}} \times \frac{1}{3600} \mathrm{E}_{\mathrm{p}}=\left(\mathrm{F}_{\mathrm{c}} \mathrm{x}\right.
$$

Where:

$\mathbf{E}_{\mathbf{p}} \quad=$ Power required, $\mathrm{kW}$;

$\mathbf{F}_{\mathbf{c}} \quad=$ the fuel consumption, $\mathrm{L} / \mathrm{h}$;

$\boldsymbol{\rho}_{\mathbf{F}} \quad=$ the density of fuel, (for solar fuel), $0.85 \mathrm{~kg} / \mathrm{l}$; 
L.C.V = lower calorific value of fuel,(average 1.c.v.of solar fuel is $10000 \mathrm{k} \mathrm{Cal} / \mathrm{kg}$ );

$\boldsymbol{\eta}_{\mathbf{t h}}=$ thermal efficiency of the engine,(considered to be $35 \%$ for diesel engine).

$\mathbf{4 2 7}=$ thermo - mechanical equivalent, $\mathrm{kg} . \mathrm{m} / \mathrm{k} . \mathrm{Cal}$, and

$\boldsymbol{\eta}_{\mathbf{m}}=$ mechanical efficiency of the engine, ( considered to be $80 \%$ for diesel engine)

The energy required ( ER ) for chopping rice straw was estimated using the following equation:

Energy requirements $=$

$\frac{\text { Power }(k w)}{\text { machineproductivity } M g / h}, k W . h / M g$,

\section{6- Estimation chopping cost:}

The total hourly cost of chopping rice straw using the forage chopper could be estimated by the following equation according to ELAwady, 1978 as follows:

$$
+\boldsymbol{\alpha}+\mathbf{r})+(\mathbf{0 . 9} \mathbf{w} \mathbf{x} \mathbf{f} \mathbf{x} \mathbf{u})+\mathbf{b}, \ldots \ldots \ldots \ldots \ldots \ldots \ldots \ldots . . .7 \frac{i}{2}+\frac{1}{L}\left(\frac{P}{h} \mathbf{C}=\right.
$$

where;

$\mathbf{C}=$ cost per hour of operation, L.E/h;

$\mathbf{P}=$ estimated price of the machine, 9000 L.E for chopper machine;

$\mathbf{h}=$ estimated yearly hour operation ,1000 for chopper machine;

$\mathbf{L}=$ life expectancy of the machine, 10 years;

$\mathbf{I}=$ annual interest rate, $10 \%$;

$\boldsymbol{\alpha}=$ annual taxes and overheads, $2 \%$;

$\mathbf{r}=$ annual repair and maintenance rate, $18 \%$;

$\mathbf{0 . 9}=$ correction factor for rated load ratio and lubrication;

$\mathbf{w}=$ engine power, $65 \mathrm{hp}$;

$\mathbf{f}=$ specific fuel consumption, L/hp.h;

$\mathbf{b}=$ hourly labor wage, $3 \mathrm{~L} / \mathrm{hp} . \mathrm{h}$;

$\mathbf{u}=$ fuel price, $0.75 \mathrm{~L} . \mathrm{E} / \mathrm{L}$. 


\section{RESULTS AND DISCUSSION}

The obtained results were discussed as follows:

\section{a ) Chopping length:}

Results concerning chopping length under different studied variables indicated that the values of cutting length increase as the machine forward speed increase, and decreased slightly as straw moisture content increased .Meanwhile the cutter head knives speed increase tends to decrease the chopping length as shown in Fig.2.It is clear that the increment in forward speed from 2.0 to $4.5 \mathrm{~km} / \mathrm{h}$ tends to increase the chopping length from 14.0 to $17.0,16.0$ to 19.0 and 18.0 to $22.0 \mathrm{~mm}$ at straw moisture content of about 40.0, 25.0 and $15.0 \%$, respectively. Whilest, the increase of cutter head knives speed from 23.0 to $33.0 \mathrm{~m} / \mathrm{s}$ tends to decrease the chopping length from 14.0 to $10.5,16.0$ to 13.2 and 18.0 to $15.4 \mathrm{~mm}$ at the same mentioned above straw moisture content and forward speed of $2.0 \mathrm{~km} / \mathrm{h}$.

\section{b) Machine productivity :}

In gradually as machine forward speed, cutter head knives speed and straw moisture content increased. On the other hand, increasing machine forward speed from 2.0 to $4.5 \mathrm{~km} / \mathrm{h}$ at straw moisture content $40.0 \%$ and cutter head knives speed $33.0 \mathrm{~m} / \mathrm{s}$ cause a corresponding increase in machine capacity from 1.50 to $1.70 \mathrm{Mg} / \mathrm{h}$. The maximum machine capacity were recorded during chopping process by using a forward speed of $4.5 \mathrm{~km} / \mathrm{h}$, straw moisture content of $40.0 \%$ and cutter head knives speed of $33.0 \mathrm{~m} / \mathrm{s}$, were $1.700 \mathrm{Mg} / \mathrm{h}$. Meanwhile, the lowest machine capacity $1.092 \mathrm{Mg} / \mathrm{h}$ were recorded by using $2 \mathrm{~km} / \mathrm{h}$, straw moisture content of $15.0 \%$ and cutter head knives speed $23.0 \mathrm{~m} / \mathrm{s}$ as shown in Fig. 3.

\section{c) Degree of destruction:}

The degree of destruction is affected by the machine forward speed, cutter head knives speed and straw moisture content as shown in Fig. 4. It is noticed that increasing the machine forward speed from 2.0 to 4.5 $\mathrm{km} / \mathrm{h}$ tends to decrease the degree of destruction from 62.0 to $57.0 \%$ at straw moisture content of $15.0 \%$ and cutter head knives speed of 33.0 $\mathrm{m} / \mathrm{s}$. The results show that the forward speed of $2.0 \mathrm{~km} / \mathrm{h}$ destroyed the highest number of stem borer in the infested rice straw. Also, it can be 
concluded that increasing cutter head knives speed from 23.0 to $33.0 \mathrm{~m} / \mathrm{s}$ tends to increase the degree of destruction from 52.0 to $62.0 \%$ at straw moisture content $15.0 \%$ and forward speed of $2 \mathrm{~km} / \mathrm{h}$. The results show that the cutter head knives speed of $33.0 \mathrm{~m} / \mathrm{s}$ destroyed the highest number of stem borer in the infested rice straw. These results agreed with that obtained by $\mathbf{E l}$ - Khateeb, 2001. The maximum values of degree of destruction were $65.0 \%$ at forward speed of $2 \mathrm{~km} / \mathrm{h}$, straw moisture content of $40.0 \%$ and cutter head knives speed of $33.0 \mathrm{~m} / \mathrm{s}$.

\section{d) Chopping efficiency:}

The chopping efficiency is affected by the machine forward speed, cutter head knives speed and straw moisture content as shown in Fig. 5. It is evident that increasing the machine forward speed from 2.0 to $4.5 \mathrm{~km} / \mathrm{h}$ tends to decrease the chopping efficiency from 88.0 to $83.0 \%$ at straw moisture content of $15.0 \%$ and cutter head knives speed of $33.0 \mathrm{~m} / \mathrm{s}$. Also, it can be concluded that increasing cutter head knives speed from 23.0 to $33.0 \mathrm{~m} / \mathrm{s}$ tends to increase the chopping efficiency from 79.0 to $88.0 \%$ at straw moisture content of $15.0 \%$ and forward speed of 2.0 $\mathrm{km} / \mathrm{h}$.The other straw moisture content gave the same above mentioned trend. These results are confirmed with those obtained by El - Khateeb, 1991. The maximum values of chopping efficiency were $91.0 \%$ at forward speed of $2 \mathrm{~km} / \mathrm{h}$, cutter head speed of $33.0 \mathrm{~m} / \mathrm{s}$ and straw moisture content of $40.0 \%$.

\section{e) Energy requirements:}

Results concerning energy requirements under different machine forward speeds, different cutter head knives speed and straw moisture content are shown in Fig. 6. The data indicated that the required energy (kW.h/Mg) for chopping operation increased from 3.198 to 3.817 $\mathrm{kW} . \mathrm{h} / \mathrm{Mg}$ as the machine forward speed increased from 2.0 to 4.5 $\mathrm{km} / \mathrm{h}$. Also, obvious that the increase cutter head knives speed from 23.0 to $33.0 \mathrm{~m} / \mathrm{s}$ tends to increase required energy from 2.593 to $3.198 \mathrm{~kW} . \mathrm{h} / \mathrm{Mg}$ at machine forward speed of $2.0 \mathrm{~km} / \mathrm{h}$ and straw moisture content of $40.0 \%$. Also, by increasing straw moisture content from 15.0 to $40.0 \%$ tends to decrease the required energy from 3.281 to $2.593 \mathrm{~kW} . \mathrm{h} / \mathrm{Mg}$, at machine forward speed of $2.0 \mathrm{~km} / \mathrm{h}$ and cutter head knives speed of $23.0 \mathrm{~m} / \mathrm{s}$. 


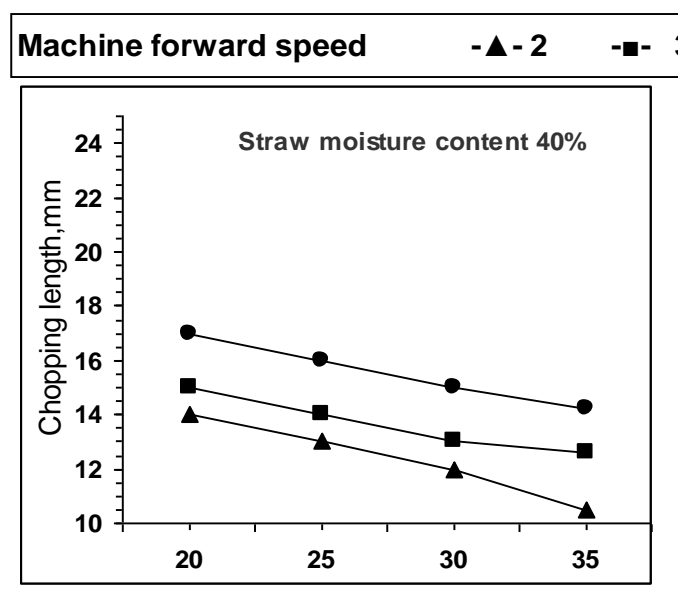

\section{$3.1-0-4.5 \mathrm{~km} / \mathrm{h}$}
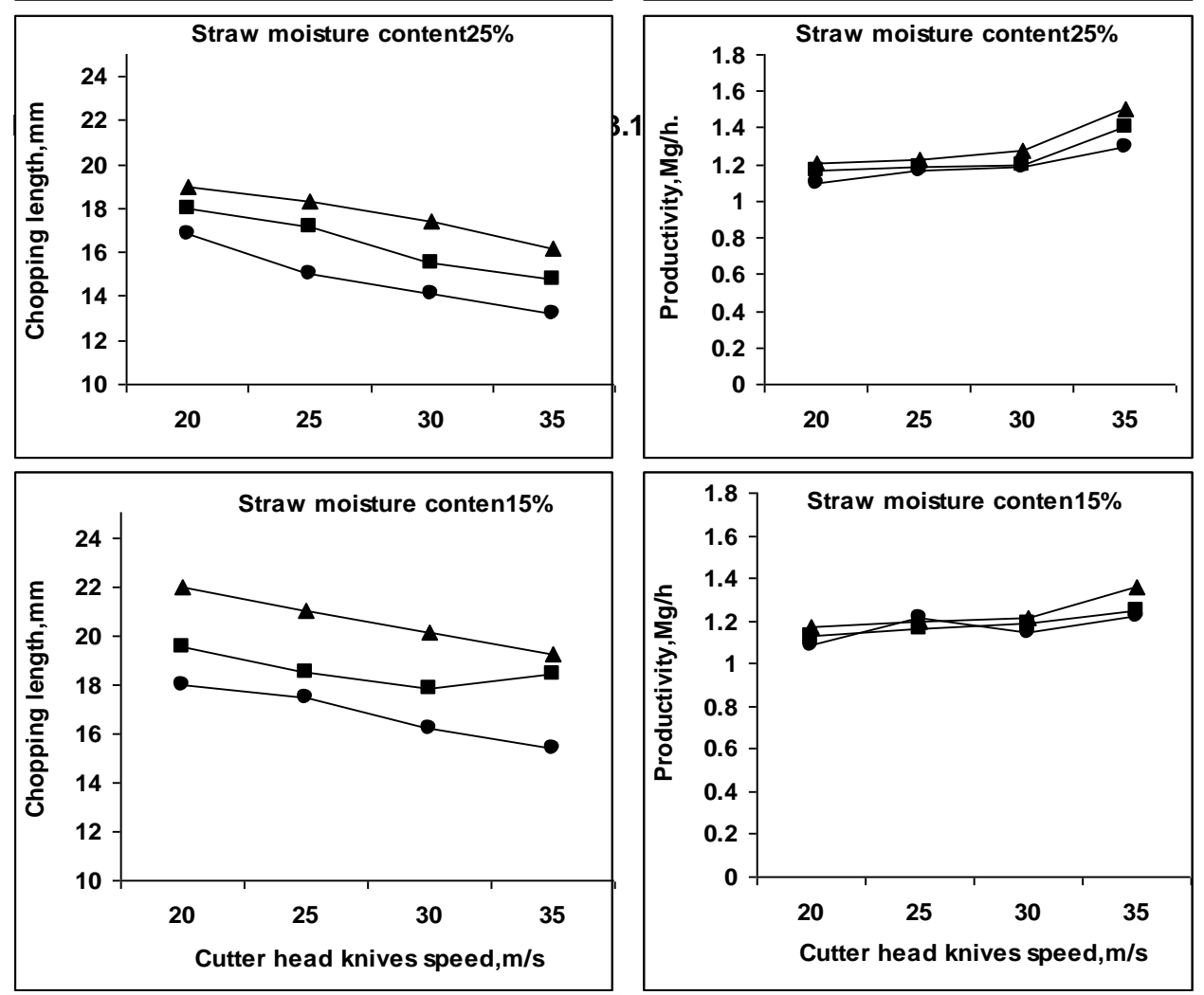

Fig. 2 : Effect of cutter head knives speed on effect of chopping length at different forward

Fig.3: Effect of cutter head knives speed speeds. onproductivity at different forward speeds. 


\section{FARM MACHINERY AND POWER}
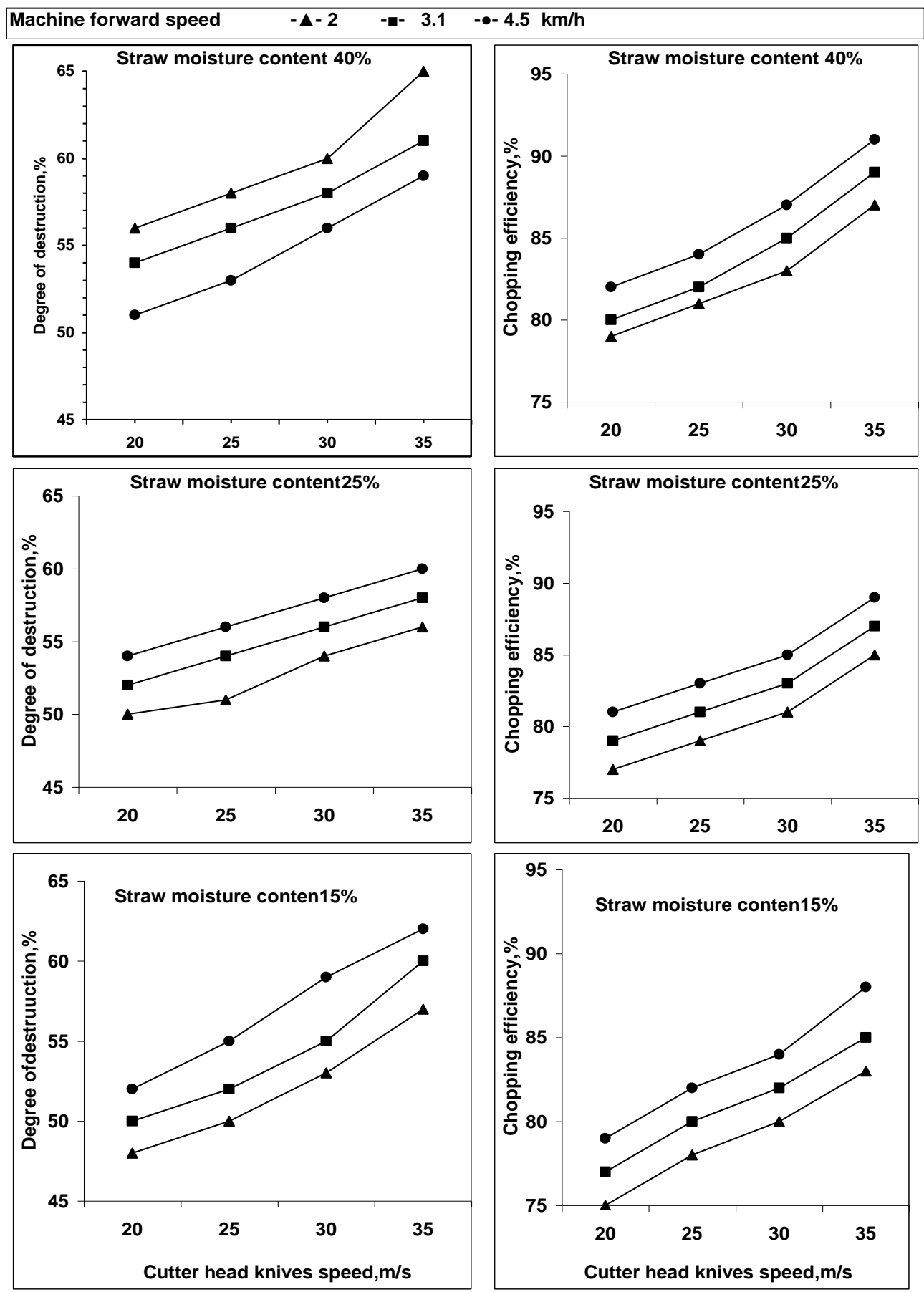

Fig.4: Effect of cutter head knives speed on degree of destruction, at different forward speeds.

Fig.5: Effect of cutter head knives speed on chopping efficiency at different forward speeds. 

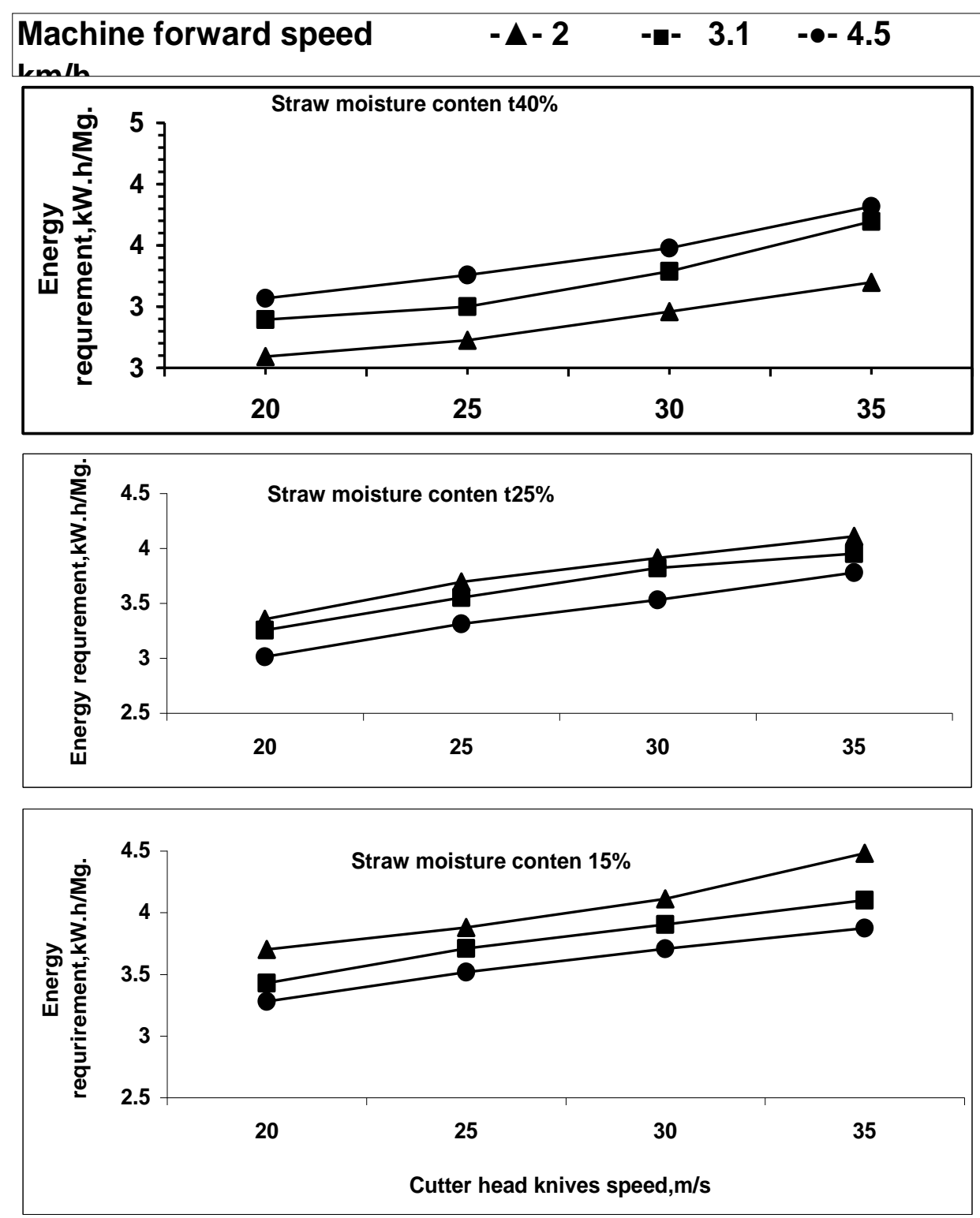

Fig.6: Effect of cutter head knives speed on energy requirement, at different forward speeds. 
These results are confirmed with those obtained by Metwalli, et. Al.,1995.

\section{f) Chopping cost:}

The chopping machine cost of straw residues was estimated. It could be cleared that the chopping machine cost indicated that by increasing the implement forward speed tends to increase the costs of chopping operation in L.E/h. It is noticed that the obtained values of total costs were found to be $6.60,8.51$, and $10.50 \mathrm{~L} . \mathrm{E} / \mathrm{h}$ at forward speed of 2.0, 3.1 and $4.5 \mathrm{~km} / \mathrm{h}$, respectively. It is also found that the unit cost L.E/Mg, increased from 5.5, 6.8 and $7.90 \mathrm{~L} . \mathrm{E} / \mathrm{Mg}$ when the machine forward speed increased from $2.0,3.1$ and $4.5 \mathrm{~km} / \mathrm{h}$.

\section{CONCLUSION}

From the above results the following conclusion are derived:

1- The minimum values of chopping length $10.5 \mathrm{~mm}$ were occurred at straw moisture content of $40.0 \%$, cutter head knives speed of 33.0 $\mathrm{m} / \mathrm{s}$ and machine forward speed of $2.0 \mathrm{~km} / \mathrm{h}$.

2- The maximum values productivity for straw chopper was $1.70 \mathrm{Mg} / \mathrm{h}$ at straw moisture content of $40.0 \%$, cutter head knives speed of 33.0 $\mathrm{m} / \mathrm{s}$ and machine forward speed of $4.5 \mathrm{~km} / \mathrm{h}$.

3 - The results illustrated that the maximum values of chopping efficiency and degree of destruction were 91.0 and $65.0 \%$ at straw moisture content of $40.0 \%$, cutter head knives speed of $33.0 \mathrm{~m} / \mathrm{s}$ and machine forward speed of $2.0 \mathrm{~km} / \mathrm{h}$.

4- From the energy point of view it can be stated that, the highest value of unit energy $4.482 \mathrm{~kW} . \mathrm{h} / \mathrm{Mg}$ at straw moisture content of $15.0 \%$, cutter head knives speed of $33.0 \mathrm{~m} / \mathrm{s}$ and machine forward speed of $4.5 \mathrm{~km} / \mathrm{h}$.

5- It is noticed that the forward speed of $2.0,3.1$ and $4.5 \mathrm{~km} / \mathrm{h}$ gave the unit cost of 5.5, 6.8 and 7.9 L.E/Mg, respectively.

6- The results of this study may be recommended that using the chopper machine for chopping rice straw residues at straw moisture content of $40.0 \%$, cutter head knives speed of $33.0 \mathrm{~m} / \mathrm{s}$ and machine forward speed of $2.0 \mathrm{~km} / \mathrm{h}$ gave the minimum values of chopping length, the maximum values of chopping efficiency, degree of destruction and minimum cost . 


\section{REFERENCES}

Arfa, G.K.(2007). Sub dual of stationary thresher machine for chopping residues. Misr J.Ag.Eng., 24 (3): 504-521.

Cravcenco, V.L.Emill; J.Cuza and F.Mihai (1976). The guide of the Ag.Mech.Eng.,Hand book. Minnistry of Agric. And food industries,Bucharest.PP.147 .

Ebaid,M.T.(2006). Possibility of utilization corn Sheller for chopping cotton an corn stalks. J.Ag.Sci. Mansoura Univ., 31(7): 121-130.

El-Awady, M.N.(1978). Engineering of tractors and agricultural machinery, tex Bk.,Col. Agric. Ain-Shams Univ.

El-Khateeb,H.A.(1991). A study on cutting and chopping cotton stalks by mowing machines. M.Sc. Thesis, Ag.Eng.Dept.,Fac. of Agric., Tanta Univ. Egypt.

El-Khateeb,H.A.(2001). Performance evaluation of using rotary mower in cutting and chopping of corn stalks. Misr J.Ag.Eng., 18 (3): 461474.

El-Khateeb,H.A.(2007). Effect of engineering parameters of residues chopper on

chopper quality. J.Ag.Res., Kafr El-Sheikh Univ., 33 (1): 1-15.

Embaby, A.T.(1985). A comparison of the different mechanization systems of cereal crop production. M.Sc.Thesis Agric. Eng., Cairo Univ.

Hanna, G.B.;A.E.Suliman;S.Younis and A.Z.Taib (1985). Evaluation of different mechanical methods of cotton stalks removal. Misr J.Ag.Eng., 2 (1): 3-25.

Imara,Z.M.; R.M.Kolief and R.Abou-Shie (1998). Cutting parameters affecting the performance of stationary chopper and silage quality.Misr J.Ag.Eng., 15 (3): 555-568.

Kamel,O.M..;M.Iraq and M.Egela (2003). Maximizing utilization of forage chopper for chopping rice straw residues Misr J.Ag.Eng., 20 (3): 751-766. 
Khadder,S.S.B.(1997). Development of a simple cutting system using the field wastes in small farms Ph.D. Thesis, Fac. Of Ag., Zagazig Univ. Egypt.

Mady,M.A. (1999). Developing a manual cutting machine suitable for cutting of corn stalks. Misr J. Agr. Eng., 16(3): 449-459.

Mohamed,M.A.;G.H.El-Sayed and K.Hegazey(1999). Some factors affecting power and energy requirements for forage harvester. Misr J.Ag.Eng., 16 (4): 757-769.

\section{Metwalli,M.M.; M.A.Helmy; S.M.Gommaa and H.A.El-}

Khateeb(1995).

Evaluation of different

mechanical method of cutting and chopping cotton stals. Misr J.Ag.Eng., 12 (1): 205-217.

Metwally,M.A.; I.F.Sayed-Ahmed; N.El-Desoukey and A.B.ElNagar(2006). Development of a chopping machine for Agricultural residual ( A case study on grape trashes).J.Agric.Sci.Mansoura Univ., 31(50): 2943-2955.

Srivastava,A.K.; C.E.Goering and R.P.Rohrbach(1995). Engineering principles of Ag.Mmachines.Hay and forage harvesting ASAE Text book Number 6 published by the ASAE Pamela DoverHansen,Editor.

Tarek,H.M.; S.Younis; M.Ghnimy and M.Baiomy(2001).

Development of rice straw chopper. Misr J.Ag.Eng., 18 (4): 173-184.

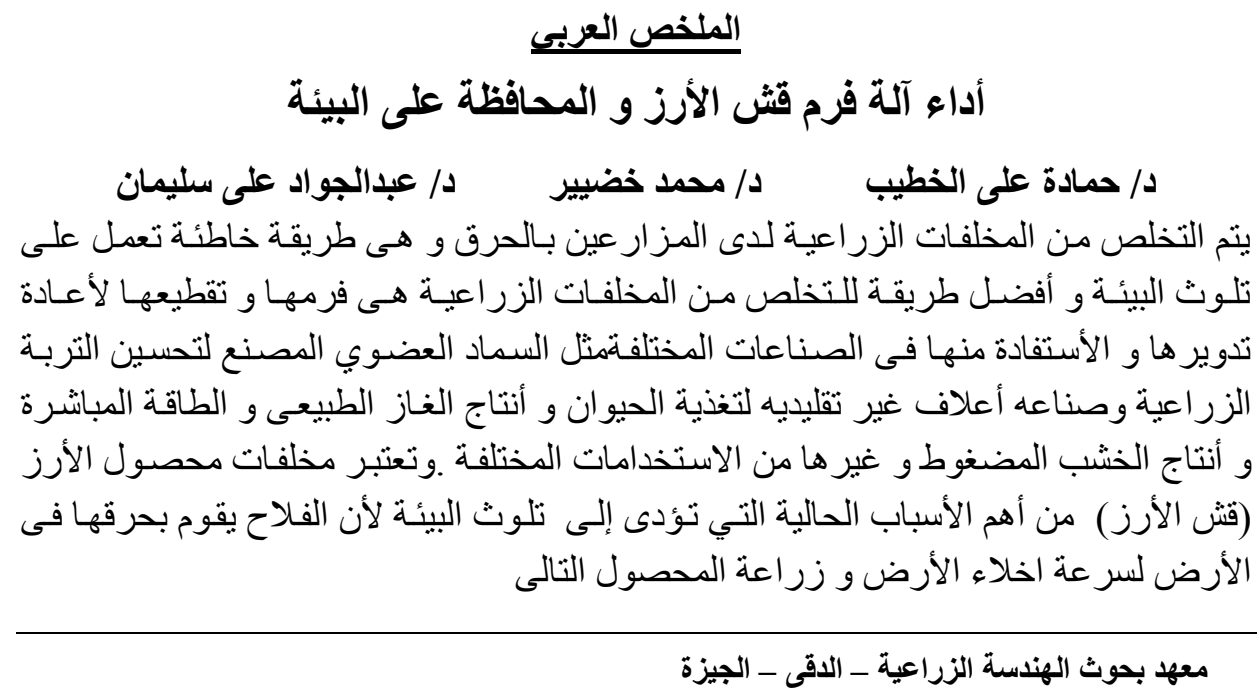


و لذللك قامـت فكرة هذا البحـث للأسـفادة مـن فش الأرز بواسطة آلـة فرم الأعـلاف لتعظيم

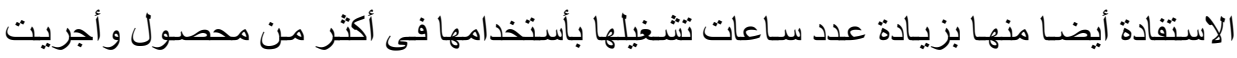

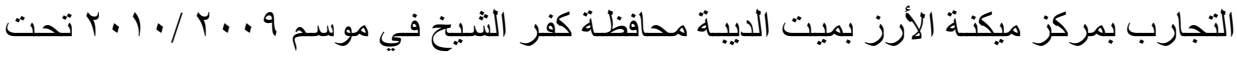
تأثنير المتغير ات الأتبة:

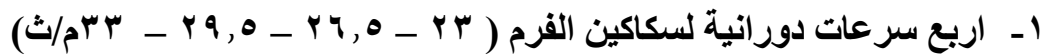

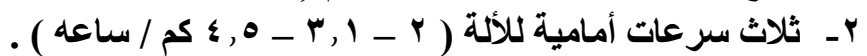

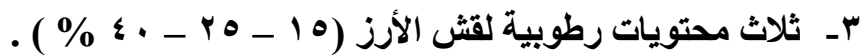

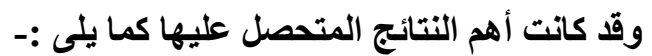

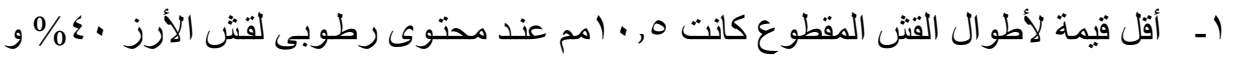

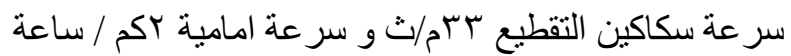

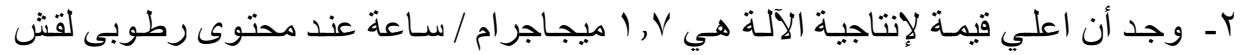

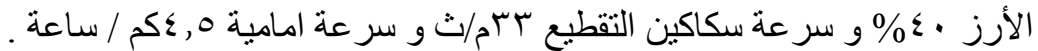

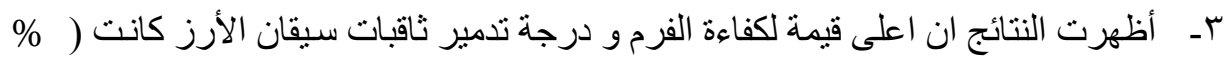

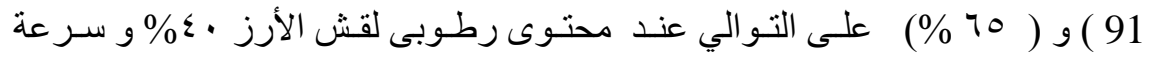

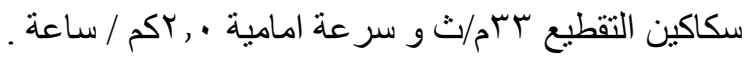

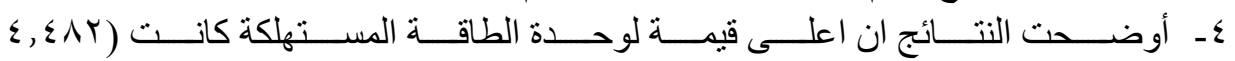

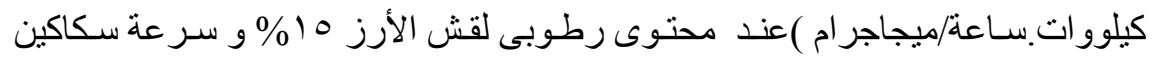

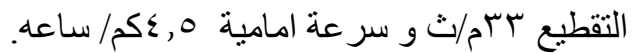

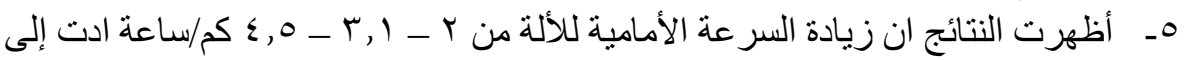
زيادة التكاليف من

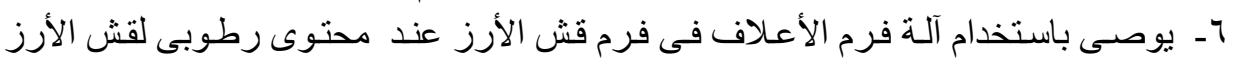

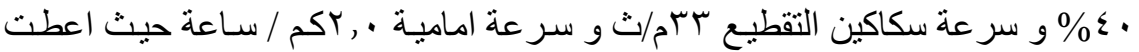

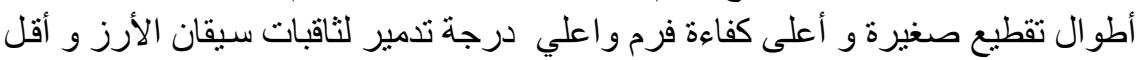
تكاليف 